\title{
A seedsnipe (Aves, Charadriiformes, Thinocoridae) from the Ensenadan Age/Stage (early-middle Pleistocene) of Buenos Aires, Argentina
}

\author{
Mariana B. J. Picasso, Ricardo S. De Mendoza and Javier N. Gelfo \\ División Paleontología Vertebrados, Museo de la Plata, Facultad de Ciencias Naturales y Museo, Universidad Nacional de la Plata, Consejo Nacional de \\ Investigaciones Científicas y Técnicas (CONICET), La Plata, Argentina
}

\begin{abstract}
The fossil record of the Charadriiformes in South America is scarce and limited to the Neogene of Argentina and Peru. In the present contribution, we present and describe a nearly complete tarsometatarsus of Thinocorus rumicivorus (Least Seedsnipe) from the Ensenadan Age/Stage (early-middle Pleistocene) of Punta Hermengo, Buenos Aires province, Argentina, which constitutes the youngest record for the species to date. We also compare the material with extant and fossil Thinocoridae. The stratigraphic range of the fossil predates the Matuyama/Brunhes boundary and is coincident with the biozone of Mesotherium cristatum, which indicates a more humid and warmer climate than the present for the species.
\end{abstract}

ARTICLE HISTORY

Received 9 August 2017

Accepted 19 August 2017

\section{KEYWORDS}

Tarsometatarsus; Scolopaci; Thinocorus; Pampean region; Neogene

\section{Introduction}

The Charadriiformes (shorebirds and allies) are a diverse highlevel taxon of birds, which, at present, occupy many different habitats, from the open sea and coastal shores to semideserts (Mayr 2009). The fossil record of the Charadriiformes in South America is scarce and limited to the Neogene of Argentina and Peru (Campbell 1979; Tambussi et al. 1993; Cenizo and Agnolin 2007; Agnolin and Chafrat 2015) and the oldest South American Charadriiformes record corresponds to an indeterminate genus and species from the early Miocene of the Chichinales Formation, in the Patagonian locality of Paso Córdoba, Río Negro province, Argentina (Agnolin and Chafrat 2015). Molecular data have provided a robust framework for the interrelationships of the various groups of Charadriiformes, which fall into three clades: the Lari, the Charadrii, and the Scolopaci (Paton and Baker 2006; Baker et al. 2007; Fain and Houde 2007; Mayr 2011).

The Scolopaci is an interesting clade because it includes representatives with a worldwide distribution and more than one hundred species, like the Scolopacidae (sandpipers and allies), and other representatives with less specific diversity and a restricted geographical distribution, such as the Thinocoridae (seedsnipes), with four species and the Pedionomidae (plains-wanderers), with a single species, both of which restricted to South America and Australia respectively. Instead, the Jacanidae (jacanas), with eight species, and the Rostratulidae (painted-snipes), with three $s$ pecies, both of which with a broader geographical distribution (Gibson and Baker 2012; Clements et al. 2016).

The Thinocoridae (seedsnipes) are small to medium-sized birds, with short legs and bills, endemic to South America, which inhabit arid environments like the grasslands and semi-deserts of Patagonia and those of the Andean zone from Ecuador to the southern tip of South America at $50^{\circ} \mathrm{S}$ in the Isla Grande de
Tierra del Fuego, Argentina (Fjeldså 1996). Extant seedsnipes differ from most other Charadriiformes in being strictly herbivorous (Fjeldså 1996) and are represented by two genera: Attagis, which includes A. gayi Geoffroy Saint-Hilaire \& Lesson, 1831 (Rufousbellied Seedsnipe), the largest species of the family $(\sim 28 \mathrm{~cm})$, and A. malouinus (Boddaert 1783) (White-bellied Seedsnipe) and Thinocorus, represented by two extant species (T. orbignyianus Geoffroy Saint-Hilaire \& Lesson, 1831 (Grey-breasted Seedsnipe) and T. rumicivorus Eschscholtz, 1829 (Least Seedsnipe)) and one extinct species (see below). T. orbignyianus is associated with the Andean grass steppes, from higher latitudes in Patagonia up to lower ones in Peru, and T. rumicivorus, the smallest species of the family $(\sim 20 \mathrm{~cm})$, is more characteristic of sandy or arid areas in the southern lowlands and on the upland plateau in the east of the Andes Range, and clay-pans with stationary water bodies. The fossil representatives of the Thinocoridae are known from fragmentary bones found in the late Miocene (Agnolin et al. 2016) and early-middle Pleistocene (Campbell 1979; Tonni et al. 1998; Seymour 2015) as well as from remains found in the Late Pleistocene (Campbell 1979; Seymour 2015). The specimen from the late Miocene is a fragmentary tarsometatarsus from the Loma de Las Tapias Formation, at the homonymous locality in San Juan province, Argentina (Agnolin et al. 2016), whereas the specimen from the early-middle Pleistocene (Ensenadan age- Cione et al. 2015) is represented by a fragment of a corpus femoris and a tarsometatarsus from Punta Hermengo, Buenos Aires province, Argentina, briefly mentioned in a taxonomic list (Tonni et al. 1998), but neither described nor illustrated, and currently unavailable at the Museo de La Plata (MLP) collection, La Plata, Argentina. Late Pleistocene records from the deposits of Talara Tar-seeps in Peru include remains of two humeri: one identified as Thinocorus koepckeae and the other identified as a 
representative of the extant species T. rumicivorus (Campbell 1979; Seymour 2015).

In the current contribution, we present the first record of Thinocorus rumicivorus from the Ensenadan levels (early-middle Pleistocene) of Buenos Aires province, Argentina. Given the scarcity of the fossil record for seedsnipes, this contribution is a significant addition to the knowledge of the extinct avifauna of South America. In the present work, we describe, compare and illustrate this fossil specimen, and discuss the possible paleobiogeographic implications of this finding in the Ensenadan paleoclimatic context, particularly considering the third main glaciation event in South America.

\section{Materials and methods}

The fossil material (MLP 01-X-12) is housed in the collection of the División Paleontología Vertebrados, Museo de La Plata (MLP), Buenos Aires, Argentina. The tarsometatarsi used for comparisons belong to the collections of the Sección Ornitología of the Museo Argentino de Ciencias Naturales Bernardino Rivadavia (MACN), Buenos Aires, Argentina (Table 1). The fossil specimen assigned to it by Tonni et al. (1998) could not be located at the MLP collection. Besides, comparison with extant specimens of Thinocorus orbignyianus failed due to the absence of skeletal materials of this taxon at the collections consulted.

The following measures were taken on the tarsometatarsi of the fossil and the living Attagis gayi and Thinocorus rumicivorus (Table 1): total length (TL): taken between extreme points of the proximal and distal regions; latero-medial width of the proximal end (PW): taken between extreme points of both cotyla; latero-medial width of the distal end (DW): taken between the most medial and lateral points of trochlea metatarsi II and IV respectively; latero-medial width of corpus tarsometatarsi (LM): taken at the mid-shaft, which was located measuring half the total length; and cranio-caudal width of corpus tarsometatarsi (CC): taken at the mid-shaft. Measurements were taken with a 300 - $\mathrm{mm}$ digital caliper ( $0.01 \mathrm{~mm}$ precision). The anatomical terminology follows Baumel and Witmer (1993) and Mayr (2015) for the morphology of the hypotarsus.

\section{Geological setting}

Paleontological excavations have been done in Punta Hermengo, at Miramar city (General Alvarado County, Buenos Aires province) (Figure 1) since the nineteenth century up to date (see comments in Cenizo et al. 2011; Cione et al. 2015; Isla et al.

Table 1. Measurements ( $\mathrm{mm}$ ) of fossil MLP 01-X-12 and living specimens of Thinocoridae (see text for abbreviations).

\begin{tabular}{lccccc}
\hline & TL & PW & DW & LM & CC \\
\hline MLP 01-X-12 & 18.54 & 3.96 & 3.52 & 1.57 & 1.14 \\
T. rumicivourus & & & & & \\
MACN54874 & 17.81 & 3.43 & 3.07 & 1.42 & 1.33 \\
MACN54697 & 18.85 & 3.77 & 3.41 & 1.38 & 1.14 \\
MACN68174 & 17.46 & 3.56 & 3.31 & 1.44 & 1.22 \\
MACN68323 & 18.85 & 3.76 & 3.67 & 1.47 & 1.59 \\
MACN68516 & 16.52 & 3.45 & 3.10 & 1.35 & 1.04 \\
MACN68173 & 18.15 & 3.58 & 3.12 & 1.56 & 1.20 \\
A.gayii & & & & & \\
MACN68741 & 25.02 & 6.78 & 6.57 & 3.05 & 2.28 \\
\hline
\end{tabular}

2015). Their geology and biostratigraphic correlations with other Pleistocene localities from the Buenos Aires province coast are well discussed (see Soibelzon et al. 2009 and literature there in). The specimen here studied (MLP 01-X-12) was found $1640 \mathrm{~m}$ southwards of the classic locality named 'Farola de Punta Hermengo' (Kraglievich 1952) in a 5-m profile exposed at the coast (Figure 2). The fossiliferous level, rich in isolated teeth of Sigmodontinae and Lagostomus sp. rodents, outcrops approximately at $1.50 \mathrm{~m}$ above sea level. The sediment belongs to the Miramar Formation and is characterised by a brown-grayish to yellowish-brown silts to sandy silts, with few lithic clasts with a diameter of $5-10 \mathrm{~cm}$. Fossils were collected from the sandy lenses which were sieved. The level was considered equivalent to the Unit B of the profile of Tonni and Fidalgo (1982) done for the area, which is characterised by normal paleomagnetic polarity assigned to the Matuyama Chron (0.90-0.78 Ma) (Soibelzon et al. 2009). Biostratigraphically, the unit is part of the Biozone of Mesotherium cristatum of Cione and Tonni (2005), previously referred to as the Biozone of Tolypeutes pampaeus (Tonni and Cione 1994), which characterises the local Ensenadan Stage/Age assigned to the early-middle Pleistocene, and which matches with the most recent part of the Matuyama polarity Chron (Cione and Tonni 1995; Soibelzon et al. 2009).

\section{Systematic paleontology}

\section{CLASS AVES Linnaeus, 1758}

ORDER CHARADRIIFORMES Huxley, 1867

SUBORDER SCOLOPACI Strauch, 1978 sensu Paton et al. (2003) FAMILY THINOCORIDAE Sundevall, 1836

Thinocorus rumicivorus Eschscholtz 1829

Thinocorus rumicivorus

Referred material: MLP 01-X-12 nearly complete right tarsometatarsus without the dorsal-most portion of the hypotarsus and the distal wall of the foramen vasculare distale (Figure 3(A)(I)). Measurements: see Table 1.

\section{Description of MLP 01-X-12}

In dorsal aspect (Figure 3(A)), it can be observed that the sulcus extensorius is shallow and extends from the proximal end to the middle of the shaft, without a clear differentiation from the fossa infra cotylaris dorsalis. The proximal region of this sulcus contains the two foramina vascularia proximalia and the tuberositas $m$. tibialis cranialis. In proximal view of the extremitas proximalis (Figure 3(E)), both the cotyla medialis and lateralis show a circular contour and can be seen separated by a blunt eminentia intercotylaris. Although the hypotarsus is partially damaged, three sulci and four cristae hypotarsii can be observed (Figure 3(B)-(E)). The crista medialis hypotarsi is wider and more prominent than the remaining cristae. The medial sulci hypotarsi is shallower than the other sulci. Also, near the crista medialis hypotarsi, a canal for the passage of the tendon of the muscle flexor digitorum longus can be observed (Figure 3(E)). The crista medianoplantaris is near the hypotarsus and merges gradually into the plantar surface of the corpus tarsometatarsi. In the facies plantaris of the corpus tarsometatarsi (Figure 3(B)), a shallow sulcus flexorius delimited by low cristae plantaris medialis and lateralis can be observed. Both facies of the corpus tarsometatarsi 


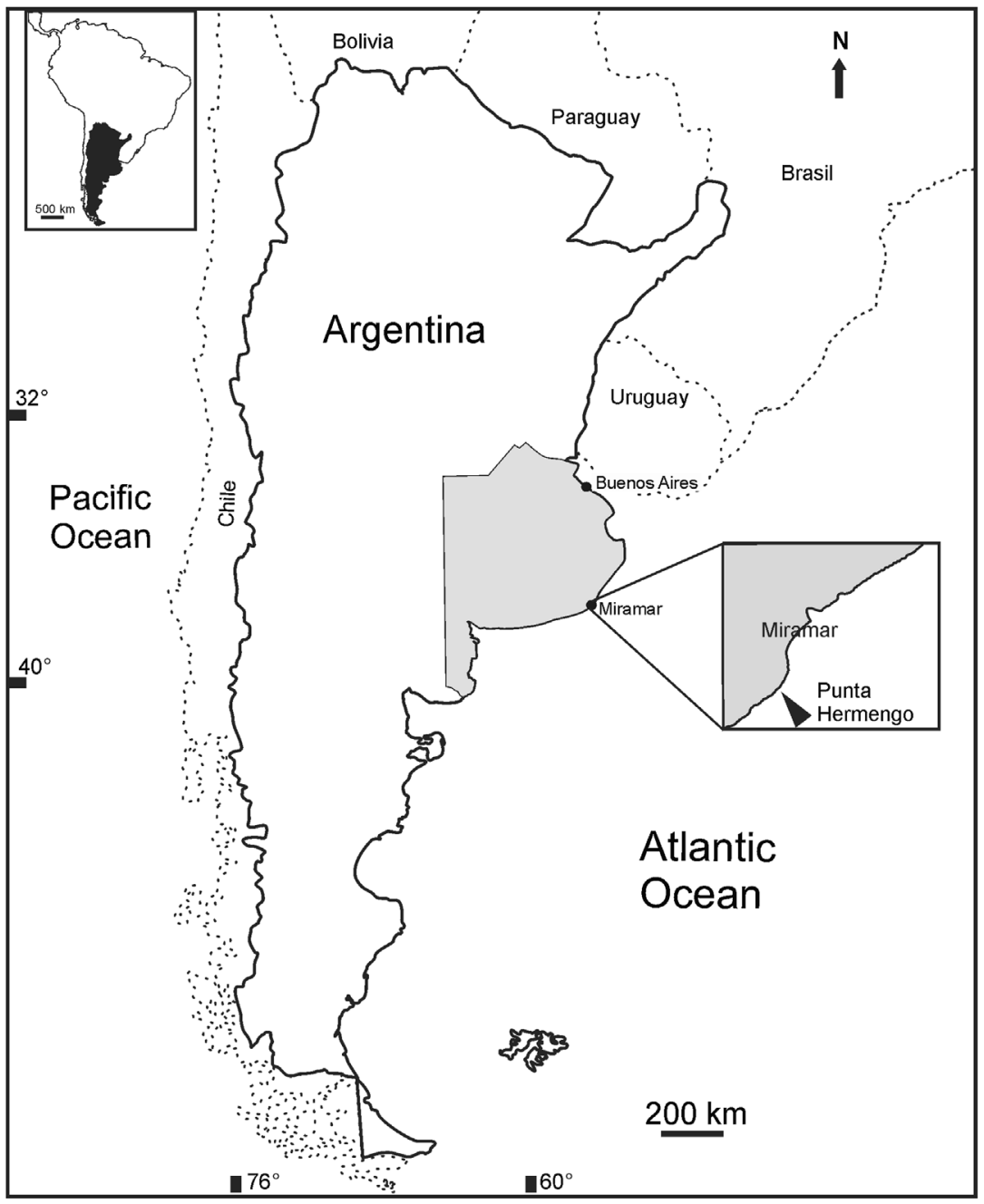

Figure 1. Map showing the geographical location of the Punta Hermengo site where the fossil MLP 01-X-12 was discovered. Source: Author.

are nearly flat, being approximately rectangular in cross-section. In the extremitas distalis, the trochlea metatarsi II, III and IV can be observed (Figure 3(F), (G)). The trochlea metatarsi II (Figure $3(\mathrm{~F}),(\mathrm{G}))$ is smaller and less prominent than the remaining ones. Plantar projections are present both in the trochlea metatarsi II and $I V$, but they are blunt and present a worn plantar surface (Figure 3(F), (G)). The trochlea metatarsi III is the largest and its rims are separated by a deep sulcus that joins to a distinctive pit of circular contour (Figure $3(\mathrm{G})$ ). The foramen vasculare distale is placed in a deep groove of the dorsal surface of the shaft, and its distal wall is missing (Figure 3(G)). In plantar view, the fossa supratrochelaris plantaris has a nearly triangular contour and a well-marked fossa metatarsi I. The dimensions of the tarsometatarsi of the fossil and the living species are shown in Table 1 (see above).

\section{Comparison with the extant Thinocoridae}

All the morphological traits of the fossil are compatible with those of Thinocorus rumicivorus (Figure 4(A)-(I)). The morphology of the cotylae, the eminetia intercotylaris, the corpus tarsometatarsi and the sulcus extensorius completely agrees with that of T. rumicivorus. Likewise, the features of the trochlea metatarsi III (Figure 4F) such as the deep sulcus and the asymmetry of the lateral rim in plantar view, the dorsal pit and the trisulcate hypotarsus with all crista hypotarsi with similar development, are very similar (Figure $4(\mathrm{E}),(\mathrm{G})$ ). The fossil dimensions are also very similar to those present in T. rumicivorus (Table 1). Instead, the tarsometatarsus of Attagis (Figure $4(\mathrm{~J})-(\mathrm{R})$ ) presents conspicuous differences with respect to those of the fossil and the living Thinocorus, being larger (see Table 1) and robust, and with a more prominent eminentia intercotylaris (Figure $4(\mathrm{~J})$ ) and a deeper pit of the trochlea III (Figure 4(P)). The fossil and the extant Thinocorus rumicivorus and Attagis gayi have similar features: the presence of plantar projections in the trochlea metatarsi II and $I V$ (compare Figure $3(\mathrm{H}, \mathrm{I})$ with Figure $4(\mathrm{H}, \mathrm{I}, \mathrm{Q}, \mathrm{R})$ ) and the morphology of the hypotarsus (Figure 3(E) and 4(E,N)). In contrast to that observed in T. rumicivorus, in the specimen here analyzed, the plantar projections in the trochlea metatarsi $I I$ and $I V$ are shorter and blunt and the dorsal margin of the trochlea metatarsi III is almost straight, not bulging dorsally. It is difficult to evaluate whether these differences are intraspecific or due to a specific variation; thus, we prefer to be cautious and assign it to T. rumicivorus. One important 

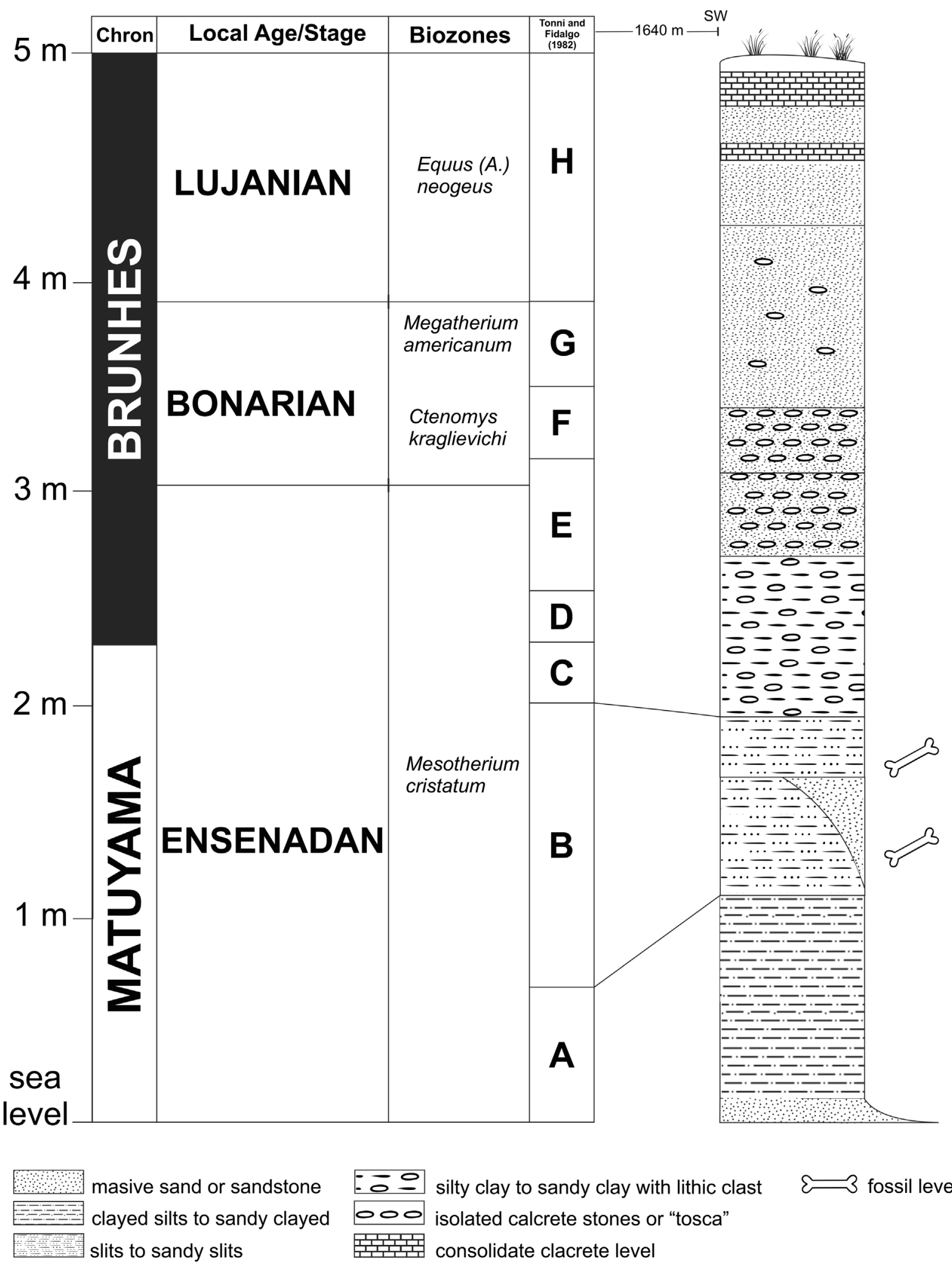

$=-0$ 으 silty clay to sandy clay with lithic clast

$\varepsilon=3$ fossil level

000 isolated calcrete stones or "tosca"

consolidate clacrete level

Figure 2. Stratigraphic profile of the fossil locality based on the profile levels of Tonni and Fidalgo (1982) indicating paleomagnetic polarity and local Stage/Age.

restriction of the present comparative analysis was the absence of skeletal materials of T. orbignyianus in the consulted collections as well as the lack of scientific literature describing it. Despite these constraints, the published data about length and body mass (Fjeldså 1996) indicated that T. orbignyianus is larger than T. rumicivorus.

\section{Discussion}

The general characteristics of MLP 01-X-12 are compatible with the tarsometatarsal morphology of the Least Seedsnipe Thinocorus rumicivorus. These include the trisulcate hypotarsus with all crista hypotarsi with similar development and a canal 

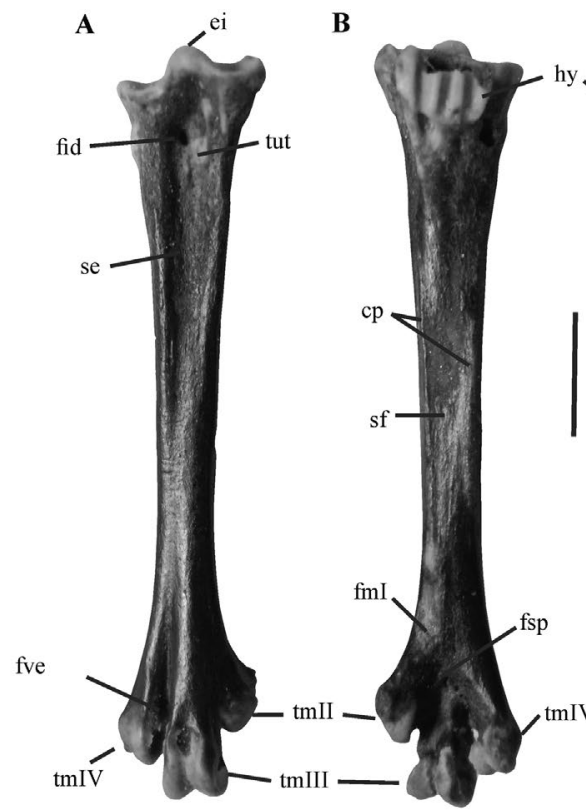

C
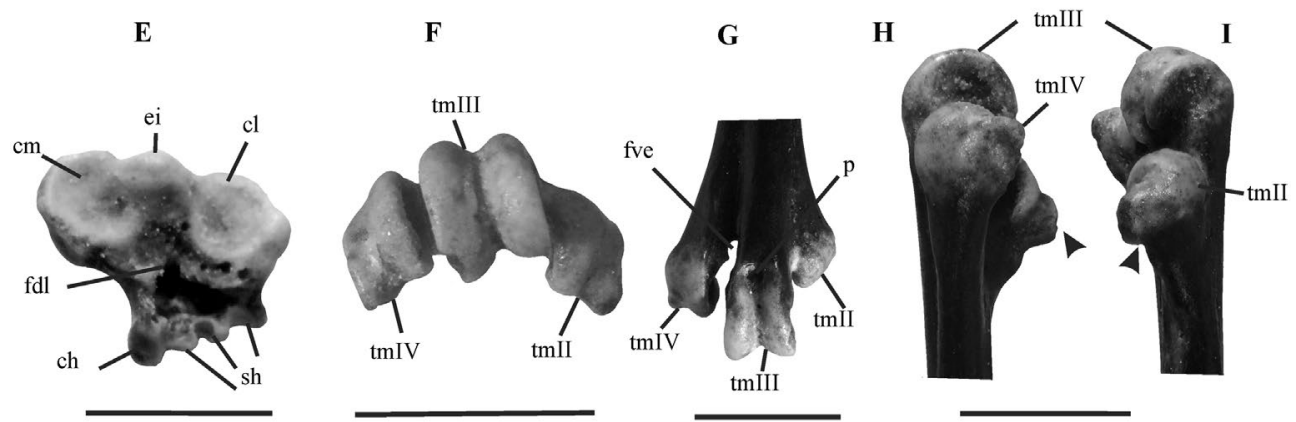

Figure 3. The MLP 01-X-12 specimen, dorsal view (A), plantar view (B); lateral view (C), medial view (D); proximal view (E); distal view (F); detailed view of the distal end showing the pit of the trochlea metatarsi III (G); detailed view of trochlea metatarsi IV (H) and trochlea metatarsi II (I). Arrows indicate the plantar projections of trochleae metatarsi II and IV.

Abbreviations: cl: cotyla lateralis, cp: cristae plantaris, cm: cotylamedialis, ch: cristae hypotarsi, fdl: canal for musculus flexor digitorum longus, fid: fossa infracotylaris dorsalis, fml: fossa metatarsi I, fsp: fossa supratrochelaris plantaris, fve: foramen vasculare distale, ei: eminentia intercotylaris, hy: hypotarsus, p: pit of the trochlea metatarsi lll, sf: sulcus flexorius, se: sulcus extensorius, sh: sulcus hypotarsii, tmll: trochlea metatarsi II, tmlll: trochlea metatarsi III, tm IV: trochlea metatarsi IV, tut: tuberositas musculus tibialis cranialis. Scale bar: $3 \mathrm{~mm}$.

for the passage of the tendon of the musculus flexor digitorum longus (lost in the fossil). It is worth mentioning that this type of hypotarsus is representative of the Scolopaci and Lari clades (Mayr 2011, 2015). The trochlea metatarsi II and IV of the fossil possess the plantar protrusions less projected than those of T. rumicivorus, but the differences may be due to the taphonomic condition of the specimen. The dorsal pit of trochlea III is deeper but shows no major differences respect to the recent Thinocoridae. This pit is absent in the Miocene Thinocoridae indet (Agnolin et al. 2016).

The specimen MLP 01-X-12 constitutes the first fossil record of T. rumicivorus for the early-middle Pleistocene of the Pampean region, and reinforces the presence of Thinocorus in the Ensenadan outcrops at Punta Hermengo zone (Tonni et al. 1998). The present fossil record indicates a confident starting point in around 0.7-0.9 Ma for the presence of T. rumicivorus in the Pampean region, a presence that is now restricted to their winter migrations when they arrive from the South West of Patagonia.

At present, the populations of the southernmost distribution of $T$. rumicivorus migrate during the winter to the northeastern of Argentina, central Chile and Uruguay (Fjeldså 1996; Narosky and Yzurieta 2003), being the only populations within the Thinocoridae that make somewhat long migrations (Ibarguchi 2011). T. rumicivorus presently inhabits a wide diversity of habitats, from sandy beaches to dry stony plains and open steppes away from the sea, even those strongly overgrazed by sheep (Fjeldså 1996). Despite its habitat preferences, the Least Seedsnipe is not present in extreme arid zones (Maclean 1969). Its low metabolic rate has been indicated as the main feature to allow its presence in arid environments (Ehlers and Morton 1982), so, its geographic distribution is probably related to the food availability. This species feeds on seeds, leaves, plant buds, and particularly succulent plants, which is supposed to be its water supply (Maclean 1969; Ehlers and Morton 1982; but see Edeelar et al. 2005).

During the Pleistocene, South American ecosystems were affected by the cyclical advance and retreat of glaciers. As a consequence, biomes underwent a clear expansion and retraction of arid and humid landscapes, sometimes favoring the development of steppes and savannas, and sometimes tropical and subtropical forests (Ortiz-Jaureguizar and Cladera 2006). The Pleistocene 

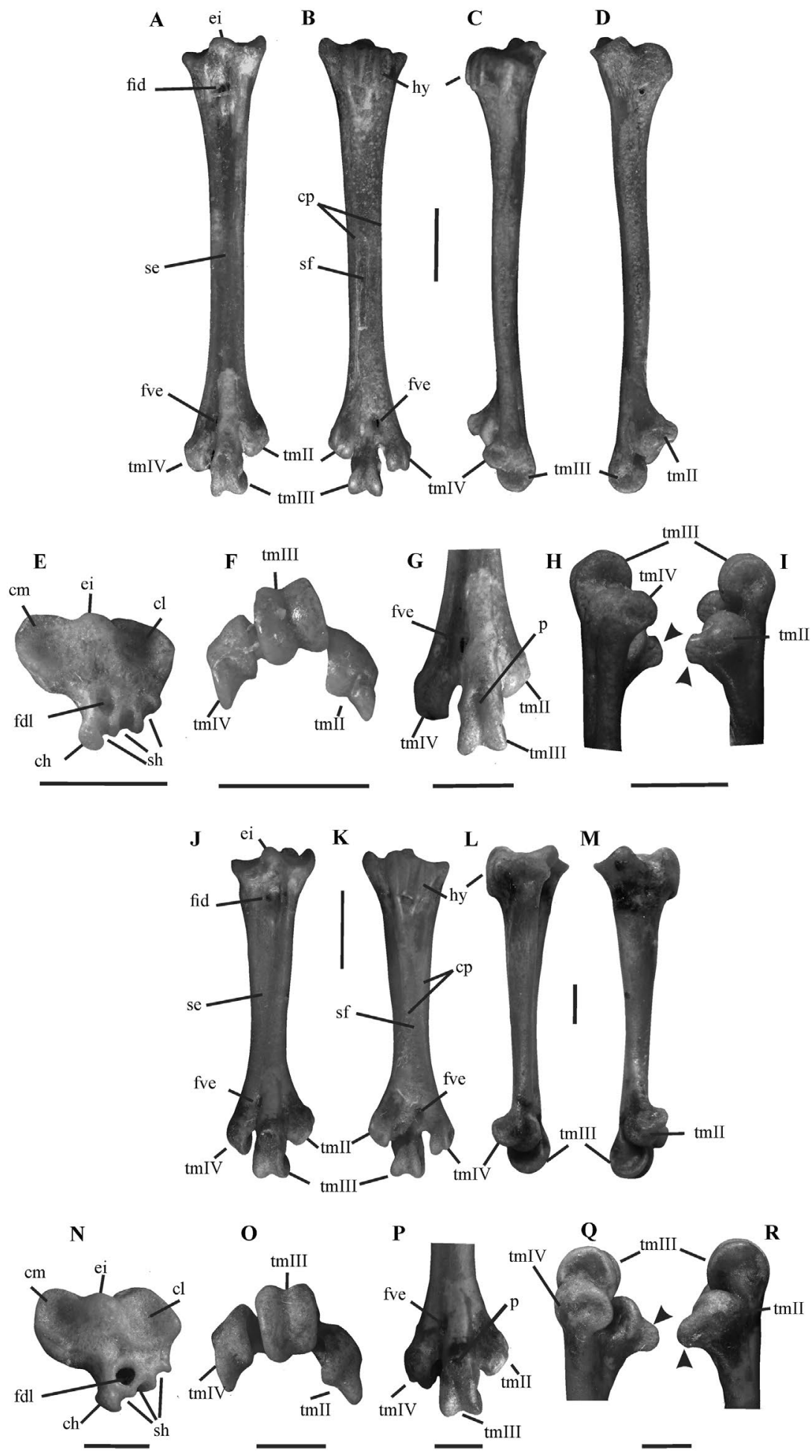

Figure 4. The Tarsometarsus of Thinocorus rumicivourus (A-I) (MACN 54697) and Attagis gayii (MACN 68741) (J-R), dorsal view (A, J), plantar view (B, K); lateral view (C, L), medial view (D, M); proximal view (E, N); distal view (F, O); detailed view of the distal end showing the pit of the trochlea metatarsi III (G, P); detailed view of trochlea metatarsi IV $(\mathrm{H}, \mathrm{Q})$ and trochlea metatarsi II (I, R).

Note: Arrows indicate the plantar projections of trochleae metatarsi II and IV. Abbreviations: cl: cotyla lateralis, cp: cristae plantaris, cm: cotyla medialis, ch: cristae hypotarsi, fdl: canal for musculus flexor digitorum longus, fid: fossa infracotylaris dorsalis, fml: fossa metatarsi l, fsp: fossa supratrochelaris plantaris, fve: foramen vasculare distale, ei: eminentia intercotylaris, hy: hypotarsus, p: pit of the trochlea metatarsi III, sf: sulcus flexorius, se: sulcus extensorius, sh: sulcus hypotarsii, tmll: trochlea metatarsi II, tmIII: trochlea metatarsi III, tm IV: trochlea metatarsi IV, tut: tuberositas musculus tibialis cranialis. Scale bar: $3 \mathrm{~mm}$.

fauna like native ungulates (i.e. Notoungulata, Litopterna), as well as several marsupial lineages, which suffered a progressive decline in their diversity through the latest Neogene to the earliest Pleistocene (Alberdi et al. 1995), were very sensitive to these environmental changes. The intensification in the arrival of northern immigrants, as part of the Great American Biotic Interchange, also contributed to modifying the Pleistocene ecosystems of the Pampean region (Weir et al. 2009; Woodburne 
2010; Cione et al. 2015). The inferences considering the mammalian fauna and the lithology (Nabel et al. 2000) indicate that the biozone of Mesotherium cristatum (early-middle Pleistocene) is coincident for the Pampean area with the presence of a wet and warm climate, which is not exactly what could be inferred from the presence of T. rumicivorus. These climatic conditions persisted up to the beginnings of Brunhes polarity Chron (0.78 Ma), when dry and cold events were identified (Nabel et al. 2000). In this more arid condition of the upper Ensenadan levels of the Pampean Region, mammals adapted to arid or cold climates (Tonni et al. 1993; Tonni and Cione 1994; Pardiñas 2004).

Considering the extant geographic distribution and chorological characteristics of T. rumicivorus mentioned above, its presence in the upper levels of the Ensenadan Age/Stage and in younger units of the middle and late Pleistocene could be expected. However, its stratigraphic record predates the Matuyama/Brunhes boundary and is coincident with a warmer and more humid climatic condition of the Pampean Region. A possible explanation is that this record indicates a wider geographic distribution or an ancient migration behavior for the Least Seedsnipe in the past, including Patagonia and the Pampean Region. The third main glaciation event that occurred in southern South America, at the onset of Brunhes Chron (i.e. 'Daniglacial') in Patagonia (Caldenius1932), 'Uspallata' in Mendoza province (Espisúa1989), and 'El Condor' in Rio Negro province (Rabassa and Evenson 1989) could be responsible for strong climatic conditions, particularly in winter in the south and east of the Least Seedsnipe distribution, triggering migration events to more benign conditions, as those in the Pampean Region. Evidence to support this speculation is scarce and this hypothesis needs to be tested or even reformulated in the light of a more profuse fossil record, in order to fill the geographical and temporal gap (from the Miocene up to the present).

\section{Disclosure statement}

No potential conflict of interest was reported by the authors.

\section{References}

Alberdi MT, Leone G, Tonni EP, editors. 1995. Biological and climatic evolution of the Pampas region during the last five million years: a correlation test with the Western Mediterranean. Monografías del Museo Nacional de Ciencias Naturales. Madrid: CSIC. Spanish.

Agnolin FL, Chafrat P. 2015. New fossil bird remains from the Chichinales Formation (Early Miocene) of northern Patagonia, Argentina. Ann Paléont. 101:87-94.

Agnolin FL, Tomassini RL, Contreras VH. 2016. Oldest record of Thinocoridae (Aves, Charadriiformes) from South America. Ann Paléont. 102:1-6.

Baker AJ, Pereira S, Paton TA. 2007. Phylogenetic relationships and divergence times of Charadriiformes genera: multigene evidence for the Cretaceous origin of at least 14 clades of shorebirds. Biol Lett. 3:205210.

Baumel JJ, Witmer LM. 1993. Osteology. In: Baumel JJ, King A, Breazile J, Evans H, Vanden Berge J, editors. Handbook of Avian Anatomy, Nomina Anatomica Avium. Cambridge (MA): Publication of Nuttall Ornithological Club 23; p. 45-131.

Caldenius CRC. 1932. The quaternary glaciations in Patagonia and Tierra del Fuego: a regional, stratigraphic and geochronological investigation, a comparison with the Swedish geochronological scale. Buenos Aires: Dirección General de Minas y Geología. Spanish.
Campbell KE. 1979. The non-passerine Pleistocene avifauna of the Talara tar seeps, northwestern Peru. Roy Ontario Mus Life Scien Contrib. 118:1-203.

Cenizo M, Agnolin F. 2007. The presence of the genus Belonopterus Reichenbach, 1852 (Aves, Charadriidae) in the Pleistocene of Argentina, with the description of Belonopterus lilloi n. sp. Rev Mus Argentino Cienc Nat. 9:41-47. Spanish.

Cenizo MM, Soibelzon E, Tonni EP. 2011. Protection of coasts and loss of paleontological heritage: the case of Punta Hermengo (Miramar, province of Buenos Aires). Rev Mus La Plata. 11:1-16. Spanish.

Cione AL, Gasparini GM, Soibelzon E, Soibelzon LH, Tonni EP. 2015. The great American biotic interchange: a South American perspective. Netherlands: Springer.

Cione AL, Tonni EP. 2005. [Biostratigraphy based on mammals of the upper Cenozoic of the province of Buenos Aires, Argentina]. In: De Barrio RE, Etcheverry RO, Caball?, MF, Llamb?as E, editors. XVI Congreso Geol?gico Argentino sep 20-23; La Plata. Buenos Aires: Universidad de La Plata- Asociaci?n Geol?gica Argentina; p.183-200 [Spanish]

Cione AL, Tonni EP. 1995. The stratotypes of the Montehermosense and Chapadmalalense (Pliocene) stages of the South American chronological scheme. Ameghiniana. 32:369-374. Spanish.

Clements JF, Schulenberg TS, Iliff MJ, Roberson D, Fredericks TA, Sullivan BL, Wood CL. 2016. The eBird/Clements checklist of birds of the world, v2016. [accessed 2017 June 16]. http://www.birds.cornell.edu/ clementschecklist/download/

Edeelar P, Abril M, Dowdall J. 2005. First record for agachonas (Thinocoridae family) drinking in the wild. Poster session presented at XI Reunión Argentina de Ornitología; 2005 Sep 7-10; Buenos Aires: Museo Argentino de Ciencias Naturales Bernardino Rivadavia. Spanish.

Ehlers R, Morton ML. 1982. Metabolic rate and evaporative water loss in the least seed-snipe, Thinocorus rumicivorus. Comp Biochem Phys A. 73:233-235.

Espisúa L. 1989. Pleistocene glacial stratigraphy in the Las Cuevas River region [dissertation]. Universidad Nacional de San Juan. Spanish.

Fain MG, Houde P. 2007. Multilocus perspectives on the monophyly and phylogeny of the order Charadriiformes (Aves). BMC Evol Biol. 7:35.

Fjeldså J. 1996. Family Thinocoridae. In: Del Hoyo J, Elliott A, Sargatal J, editors. Handbook of the birds of the world volume 3 Hoatzin to Auks handbook of birds of the world. Barcelona: Lynx; p. 538-545.

Gibson R, Baker A. 2012. Multiple gene sequences resolve phylogenetic relationships in the shorebird suborder Scolopaci (Aves: Charadriiformes). Mol Phylogenet Evol. 64:66-72.

Ibarguchi G. 2011. Biogeography and diversification of the andean seedsnipes (Thinocoridae): an antarctic avian lineage? [dissertation]. Ontario (CA): Queen's University.

Isla F, Taglioretti M, Dondas A. 2015. Review and new contributions on the stratigraphy and sedimentology of the cliffs between Mar de Cobo and Miramar, province of Buenos Aires. Rev Asoc Geol Argentina. 72:235-250. Spanish.

Kraglievich JL. 1952. The geological profile of Chapadmalal and Miramar, province of Buenos Aires. Rev Mus Mar del Plata. 1:8-37. Spanish.

Maclean GL. 1969. A study of seedsnipe in southern South America. Liv Bird. 8:33-80.

Mayr G. 2009. Paleogene fossil birds. Heidelberg: Springer.

Mayr G. 2011. The phylogeny of Charadriiform birds (shorebirds and allies) reassessing the conflict between nmorphology and molecules. Zool J Linn Soc. 161:916-934.

Mayr G. 2015. Variations in the hypotarsus morphology of birds and their evolutionary significance. Acta Zool. 2:196-210.

Nabel PE, Cione A, Tonni EP. 2000. Environmental changes in the Pampean area of Argentina at the Matuyama-Brunhes (C1r-C1n) Chrons boundary. Palaeogeogr Palaeoclimatol Palaeoecol. 162:403-412.

Narosky T, Yzurieta D. 2003. Guide for the identification of the birds of Argentina and Uruguay. Buenos Aires: Vazquez Mazzini Editores. Spanish.

Ortiz-Jaureguizar E, Cladera GA. 2006. Paleoenvironmental evolution of southern South America during the Cenozoic. J Arid Environ. 66:498-532.

Pardiñas UFJ. 2004. Sigmodontinerodents (Mammalia: Rodentia: Cricetidae) and other micromamíferos as indicators of environments towards the cuspidal Ensenadense in the southeast of the province of Buenos Aires (Argentina). Ameghiniana. 41:437-450. Spanish. 
Paton TA, Baker AJ. 2006. Sequences from 14 mitochondrialgenes provide a well-supported phylogeny of the Charadriiform birds congruent with the nuclear RAG-1 tree. Mol Phylogenet Evol. 39:657-667.

Rabassa J, Evenson EB. 1989. Review of the glacial stratigraphy of the Lake Nahuel Huapi area. Paper presented at XI Congreso Geológico Argentino; 1989 agosto 1-3; San Juan: Asociación Geológica Argentina. Spanish.

Seymour KL. 2015. Perusing Talara: overview of the Late Pleistocene fossils from the tar seeps of Peru. In: Harris JM, editor. La Brea and beyond: the paleontology of asphalt-preserved biotas. Science Series, 42. Los Angeles (CA): Natural History Museum of Los Angeles County; p. 97-109.

Soibelzon E, Prevosti FJ, Bidegain JC, Rico Y, Verzi DH, Tonni EP. 2009. Correlation of late Cenozoic sequences of southeastern Buenos Aires province: Biostratigraphy and magnetostratigraphy. Quat Int. 210:51-56.

Tambussi CP, Noriega JI, Tonni EP. 1993. Late Cenozoic birds of Buenos Aires province (Argentina): an attempt to document quantitative faunal changes. Palaeogeogr Palaeoclimatol Palaeoecol. 101:117-129.

Tonni EP, Cione AL. 1994. Mammals and climate in the Pleistocene and Holocene of the province of Buenos Aires. Paper presented at Jornadas de Arqueología e Interdisciplinas; 1994 octubre 5-8; Buenos Aires:
Consejo Nacional de Investigaciones Científicas y Técnicas, Programa de Estudios Prehistoricos. p. 127-142. Spanish.

Tonni EP, Fidalgo F. 1982. Geology and paleontology of sediments of the Pleistocene in the area of Punta Hermengo (Miramar, province of Buenos Aires, Argentina): paleoclimatic aspects. Ameghiniana. 19:79108. Spanish.

Tonni EP, Pardiñas UFJ, Verzi DH, Noriega JI, Scaglia O, Dondas A. 1998. Pleistocene microvertebrates from the southeast of the province of Buenos Aires (Argentina): Bioestratigraphy and Paleoenviroments. Paper presented at V Jornadas Geológicas y Geofísicas Bonaerenses; 1998 diciembre 9-11; Buenos Aires: Comisión de Investigaciones Científicas de la Provincia de Buenos Aires. Spanish.

Tonni EP, Verzi DH, Bargo MS, Pardiñas UFJ. 1993. Micromammals in owl pellets from the lower-middle Pleistocene in Buenos Aires Province, Argentina Buenos Aires. Ameghiniana. 30:342.

Weir JT, Bermingham E, Schluter D. 2009. The great American biotic interchange in birds. PNAS. 106:21737-21742.

Woodburne MO. 2010. The great American biotic interchange: dispersals, tectonics, climate, sea level and holding pens. J Mammal Evol. 17:245264. 